\title{
Effect of Streptozotocin (STZ) on Pancreatic Carcinogenisis
}

\author{
Chennuru Veeranjaneyulu ${ }^{1 *}$ and Gangapatnam Subrahmanayam ${ }^{2}$ \\ ${ }^{1}$ Department of Advanced ResearchCenter, Narayana Medical Institutions, India \\ ${ }^{2}$ Director \& Interventional Cardiologist, Narayana Medical Institutions, India
}

Submission: October 31, 2017; Published: November 14, 2017

"Correspondence Address: Chennuru Veeranjaneyulu, Department of Advanced Research Center, Narayana Medical Institutions, Nellore, Andhrapradesh, India, Email: veerachari1234@gmail.com

\begin{abstract}
Streptozotocin (STZ) is a one of the greatest indication of diabetogenic agent in experimental Animal works and also it can be used for therapeutic treatment of cancer in human beings. It's main occupation toxic and necrotic cell death. Its use is normally limited to patients whose cancer cannot be removed by surgery. In these patients, streptozotocin can reduce the tumor size and moderate symptoms. Streptozotocin doesn't have an effect on the pancreatic beta cells of humans when utilized in the treatment of islet-cell carcinomas and malignant carcinoid tumors in humans.
\end{abstract}

Keywords: Streptozotocin; Pancreatic; Malignancy; Symptoms

\section{Introduction}

Cancer is a class of syndromes categorized by out-ofcontrol cell growth. Cancer is when atypical cell division in an uncontrolled manner [1]. The resultant aberrant cell behavior leads to expansive masses of abnormal cells that destroy surrounding normal tissue. Cancers connecting tumor suppressor genes are frequently transmissible because a parent may deliver a germ line metamorphosis in one copy of the gene [1]. This may principally to a greateroccurrence of defeat of both genetic factors in the individual who succeed to the transmuted copy than in the general population [2]. However, variations in both copies of a tumor suppressor gene factor can occur in a somatic cell, so these cancers are not continuously hereditary. Somatic alterations that lead to the loss of their occupation of one or both copies of a tumor suppressor gene may be triggered by environmental factors, so even these ancestral cancers may have an environmental component [2].

Cancer, also so-called malignancy, is an uncharacteristic progression of cells. There are more than 100 kinds of cancer, including breast cancer, colon cancer, lung cancer, skin cancer, prostate cancer, and lymphoma. Produces protein products that normally improve cell separation or inhibit common cell death [3]. The changed methods of these genetic factors are called 'oncogenes'. Most oncogenes are governing mutations, a single replica of this gene is adequate for expression of the development trait. This is also nowa "advantage of occupation" changes because the cells with the distorted procedure of the protein have increased an innovative function not contemporary in cells with the typical gene [3]. Cancer treatment may include chemotherapy, radiation, and/or surgery. Symptoms differ depending on the category. Cancer treatment may consist of chemotherapy, radiation, and/or surgery [4].

Streptozotocin (C8H15N307) is a one of the chemical compounds which can be used as a diabetogenic agent for in diabetes for animal model research [4]. In 1963, Rakieten et al. [5] described that Streptozotocin (STZ) is diabetogenic. Again, this insulinopenia syndrome, so-called 'streptozotocin diabetes', is produced by the particular necrosis of the pancreatic beta cells and streptozotocin has been the mediator of choice for the induction of diabetes mellitus in animals ever since [6]. It is an effective for toxic and also cytotoxic glucose analogues that's notably deadly toxic to insulin, and cause a state of insulin dependent diabetes mellitus. Although their cytotoxicity is achieved via different pathways, their mechanisms of beta cell selective action are identical [7].

Therefore, Streptozocin is a nitrosourea advertised for the treatment of metastatic islet cell carcinoma of the pancreas 


\section{Cancer Therapy \& Oncology International Journal}

[8]. Because of STZ is a diabetogenic effect in animals Tuch [8], concern was elevated about human practice of the drug. However, experimental animal diabetes induced by streptozocin gives the impression not to occur in humans. Human fetal pancreatic islet cells seem to be resistant to streptozocin toxicity in assessment to rat fetal islet cells. There has been a particular explosion of a human pregnancy in which streptozocin was used. No adversative effect was detected [9].

\section{Conclusion}

Streptozotocin doesn't have an effect on the pancreatic $\beta$ cells of humans when exploited in the management of islet-cell carcinomas and malignant carcinoid tumors in humans [10]. This opposition of the human $\beta$ cells to STZ is accredited to the appropriate lower level of the constitutive GLUT 2 transporter appearance within the human $\beta$ cell [10].

\section{References}

1. Masao Sugamata, Ihara T, Miho Sugamata (2015) Mast cell infiltration and leukotriene receptor expression in various tumors: possible clinical application of common pathological findings concerned with tumor development. J Cancer Therapy 6: 606-612.

2. The Lancet (2010) Preventable cancer in USA. Lancet 375(9727): 1665.

3. Thun MJ, Henley SJ, Patrono C (2002) Nonsteroidal anti-inflammatory drugs as anticancer agents: mechanistic, pharmacologic, and clinical issues. J Natl Cancer Inst 94(4): 252-266.
4. Elwood PC, Gallagher AM, Duthie GG, Mur LAJ, Morgan G (2009) Aspirin, salicylates, and cancer. Lancet 373(9671): 1301-1309.

5. Cuzick J, Otto F, Baron JA, Brown PH, Burn J, et al. (2009) Aspirin and non-steroidal anti-inflammatory drugs for cancer prevention: an international consensus statement. Lancet Oncol 10(5): 501-507.

6. Patrignani P, Patrono C (2016) Aspirin and cancer. J Am Coll Cardiol 68(9): 967-976.

7. Savari S, Liu M, Zhang Y, Sime W, Sjölander A (2013) CysLT1R antagonists inhibit tumor growth in a xenograft model of colon cancer. PloS ONE 8(9): e73466.

8. Ming Ju Tsai, Ping Hsun Wu, Chau Chyun Sheu, Ya Ling Hsu, Wei An Chang, et al. (2016) Cysteinyl leukotriene receptor antagonists decrease cancer risk in asthma patients. Sci Rep 6: 23979.

9. Pothwell PM, Wilson M, Elwin CE, Norrving B, Algra A, et al. (2010) Long-term effect of aspirin on colorectal cancer incidence and mortality: 20-year follow-up of five randomized trials. Lancet 376(9754): 1741-1750.

10. Sugamata M, Ihara T, Uchiide I (2005) Increase of activation mast cells in human endometriosis. Am J Reprod Immunol 53(3): 120-125.

11. Ihara T, Uchiide I, Sugamata M (2004) Light and electron microscopic evaluation of antileukotriene therapy for experimental rat endometriosis. Fertil Steril 81(1): 819-823.

12. Masao Sugamata, Tomomi Ihara, Ichiro Uchiide (2015) A new therapy for human endometriosis: the therapeutic value of leukotriene receptor antagonist for endometriosis. Open J Obstet Gynecol 5: 313-318.

Your next submission with Juniper Publishers will reach you the below assets

- Quality Editorial service

- Swift Peer Review

- Reprints availability

- E-prints Service

- Manuscript Podcast for convenient understanding

- Global attainment for your research

- Manuscript accessibility in different formats ( Pdf, E-pub, Full Text, Audio)

- Unceasing customer service

Track the below URL for one-step submission https://juniperpublishers.com/online-submission.php 